\title{
Chemical fractionation of inorganic constituents in entrained flow gasification of slurry from straw pyrolysis
}

\author{
Konrad Mielke ${ }^{\mathrm{a}, *}$, Thomas Kolb ${ }^{\mathrm{b}}$, Michael Müller ${ }^{\mathrm{a}}$ \\ ${ }^{a}$ Institute of Energy and Climate Research (IEK-2), Forschungszentrum Jülich GmbH, 52425, Jülich, Germany \\ ${ }^{\mathrm{b}}$ Engler-Bunte-Institut, Karlsruhe Institut für Technologie, Engler-Bunte-Ring 1, 76131, Karlsruhe, Germany
}

\author{
Keywords: \\ Gasification \\ Ash fractionation \\ Slag \\ Viscosity \\ Biochar \\ Straw
}

\begin{abstract}
A B S T R A C T
Pressurized entrained-flow gasification (PEFG) of straw biomass is currently being studied as a potentially sustainable and economically viable process to produce fuels and other vital chemicals. In the process chain the gasification is integrated and straw is converted via pyrolysis into a bioslurry consisting of a liquid, tar-rich phase and char. Afterwards, the slurry is gasified into a tar-free, low-methane syngas which is a basic reactant for the synthesis of biofuels. At the high temperatures over $1200{ }^{\circ} \mathrm{C}$ the ash constituents of the char in the bioslurry melt and flow down the inner wall as slag. The slag viscosity has to be in a certain range to form a protective layer at the reactor wall and to guarantee a continuous removing. For this reason, the composition of the molten ash at the reactor wall has to be well known. Due to several fractionation processes in the gasifier the composition of the slag at the reactor wall does not correspond directly with the slurry ash. Therefore, experiments were conducted to identify depletion and enrichment processes in the gasifier. Finally, the composition of the slag at the reactor wall is obtained and can be used for the adjustment of the viscosity.
\end{abstract}

\section{Introduction}

Biofuels are a $\mathrm{CO}_{2}$-neutral alternative to conventional fuels which are based on fossil energy carriers. The synthesis of biofuels is achieved by Biomass-to-Liquid (BtL) technologies. Low-grade biogenic feedstocks are upgraded to high-grade synthetic fuels with high energy density. An example of a BtL-process is the bioliq process developed at the Karlsruhe Institute of Technology [1]. The basic resource is residual straw from agriculture. Because of its low energy density, straw has to be converted into an intermediate energy carrier. The technique used is fast pyrolysis at temperatures around $500{ }^{\circ} \mathrm{C}$ under inert-atmospheric conditions. This process results in solid char, liquid and aqueous condensates and non-condensables. The mixed condensates and char form a slurry that is used for feeding the high temperature pressurized entrained flow gasifier in the following process step [1-3].

In the gasifier temperatures over $1200{ }^{\circ} \mathrm{C}$ and pressures of $40-80$ bars are dominant. The resulting tar-free and low methane syngas is used as the basic reactant for synthetic biofuels and chemicals [4-6]. The high temperatures cause the ash constituents of the slurry to melt. The formed slag layer flows down the reactor wall, is separated in a quench at the outflow and removed continuously. The slag also protects the refractory material at the reactor wall against corrosion. Therefore, the viscosity of the slag at the reactor wall has to be in a certain range to prevent stalling of the protective layer at low viscosities and avoid blockages on the reactor outlet at high viscosities [7]. In the literature a typical viscosity range of $10-25 \mathrm{~Pa}^{*} \mathrm{~s}$ is suggested for slag inside entrained flow gasifiers [8].

The viscosity is primary influenced by temperature and chemical composition [9-12]. For reliable calculation of the slag viscosity, these two factors have to be well known. The temperature at the gasifier wall can be calculated by CFD and is subject of other studies [13-15]. However, the chemical composition of the slag at the reactor wall is not necessarily identical with the chemical compositions of the feedstock ash. Varying chemical composition of different straw feedstocks influence the reaction chains concerning the release and fate of volatile inorganic species [16], which in turn influence the composition and thus the viscosity of the resulting slag. Furthermore, fractionation processes occur during the gasification of the slurry in the reactor flame. Thus, knowledge about the fractionation of inorganic constituents related to the gasifier conditions and different straw compositions are mandatory for predicting the composition of slag inside the reactor, based on which its viscosity can be calculated. Therefore, the aim of the present

\footnotetext{
* Corresponding author. Institute of Energy and Climate Research (IEK-2), Forschungszentrum Jülich GmbH Wilhelm-Johnen Str., 52425, Jülich, Germany. E-mail address: k.mielke@fz-juelich.de (K. Mielke).
} 
investigation was to identify the relevant fractionation processes depending on ash composition. The results will later be used to develop a model for predicting slag composition and viscosity based on the ash composition of the fuel and the process parameters.

\section{Materials and methods}

\subsection{Materials}

The char samples investigated in this study are obtained from four types of straw collected in 2002, namely Spanish oats (Avena sativa, denominated as H2), Spanish winter barley (Hordeum vulgare, H5), Spanish carinata (Brassica carinata, H7), and Danish wheat (Triticum aestivum, H10). The straw samples, comprising hulls, stems, and leafs, were shredded $(<5 \mathrm{~cm})$, homogenized and stored under dry conditions at room temperature. For the present investigations, samples were pyrolysed at $550{ }^{\circ} \mathrm{C}$ in inert atmosphere $\left(\mathrm{N}_{2}\right)$ in a first step. The chemical analyses of the chars were performed by the Central Division of Chemical Analysis (Forschungszentrum Jülich). Major elements (C, H, N, and S) were analyzed by a CHNS analyzer (Table 1). Moisture and ash content were determined by mass loss during drying at $105{ }^{\circ} \mathrm{C}$ and ashing in air at $550{ }^{\circ} \mathrm{C}$, respectively. The oxygen was calculated by balancing to $100 \%$. The amount of chlorine was determined by ion chromatography. The inorganic fraction was analyzed by inductively coupled plasma optical emission spectroscopy (ICP OES). The normalized ash composition is shown in Fig. 1.

Each char sample has a characteristic chemical composition illustrating the wide diversity of straw concerning the distribution of inorganic constituents. The sample $\mathrm{H} 2$ is characterized by high $\mathrm{SiO}_{2}$ and $\mathrm{CaO}$ contents. $\mathrm{H} 5$ is enriched in $\mathrm{K}_{2} \mathrm{O}$ and $\mathrm{Cl}$. In $\mathrm{H} 7, \mathrm{CaO}$ und $\mathrm{K}_{2} \mathrm{O}$ are the main components. $\mathrm{H} 10$ is dominated by $\mathrm{SiO}_{2}$ and $\mathrm{K}_{2} \mathrm{O}$.

Alkaline metals (K, Na) influence the viscosity of the molten ash and volatize under gasification conditions. In the straw samples, $\mathrm{K}$ is the most abundant alkaline metal (Fig. 1). The distribution between the accompanying components $\mathrm{Si}, \mathrm{Ca}, \mathrm{Cl}$ will influence the release behavior of K significantly [17-19]. Therefore, the study will mainly focus on the content of these four elements.

Table 1

Chemical composition und element ratios of the investigated char samples.

\begin{tabular}{lllll}
\hline Mass fraction (\%) & H2 & H5 & H7 & H10 \\
\hline Char components & & & & \\
$\mathrm{C}$ & 69.54 & 61.01 & 64.94 & 64.3 \\
$\mathrm{H}$ & 3.21 & 3.57 & 3.55 & 2.95 \\
$\mathrm{~N}$ & 1.78 & 0.78 & 0.93 & 1.1 \\
Moisture & 1.58 & 4.57 & 4.48 & 2.90 \\
Ash & 11.31 & 17.65 & 12.31 & 18.96 \\
$\mathrm{O}$ (difference) & 12.57 & 12.42 & 13.78 & 9.79 \\
$\mathrm{\Sigma}$ & 100 & 100 & 100 & 100 \\
$\mathrm{Ash}$ components & & & & \\
$\mathrm{Cl}$ & 0.06 & 2.489 & 0.13 & 0.739 \\
$\mathrm{Al}$ & 0.0094 & 0.0053 & 0.00633 & 0.07 \\
$\mathrm{Ca}$ & 2.664 & 0.72 & 1.63 & 1.283 \\
$\mathrm{Fe}$ & 0.0234 & 0.00401 & 0.0061 & 0.0685 \\
$\mathrm{~K}$ & 2.44 & 6.51 & 6.5 & 5.41 \\
$\mathrm{Mg}$ & 0.236 & 0.2493 & 0.135 & 0.218 \\
$\mathrm{Na}$ & 0.455 & 0.94 & 0.0772 & 0.0693 \\
$\mathrm{P}$ & 0.393 & 0.1008 & 0.361 & 0.2645 \\
$\mathrm{~S}$ & 0.219 & 0.373 & 0.33 & 0.28 \\
$\mathrm{Si}$ & 0.972 & 1.613 & 0.032 & 3.7 \\
& & & & \\
$\mathrm{Element}$ ratios (molar basis) & & & \\
$\mathrm{K} / \mathrm{Si}$ & 1.8 & 2.9 & 145.8 & 1.0 \\
$\mathrm{~K} / \mathrm{Cl}$ & 37.0 & 2.4 & 45.4 & 6.7 \\
$\mathrm{~K} / \mathrm{Ca}$ & 0.9 & 9.3 & 4.1 & 4.3 \\
$\mathrm{Ca} / \mathrm{Si}$ & 1.9 & 0.3 & 35.6 & 0.2 \\
\hline
\end{tabular}

\subsection{Sample preparation and gasification}

The char from the previous pyrolysis step was grinded to a size $<1$ $\mathrm{mm}$. According to the process conditions of the bioliq ${ }^{\circledR}$-process a model fuel consisting of 20 mass $\%$ pyrolysis char as solid phase and 80 mass $\%$ ethylenglycol $\left(\mathrm{C}_{2} \mathrm{H}_{6} \mathrm{O}_{2}\right)$ as liquid phase was created [20]. $200 \mathrm{mg}$ of slurry were filled into a Pt-sample boat in each experiment.

Several investigations used the high-temperature furnace reactor combined with the MBMS instrument [19,21,22]. The experimental setup in this study is based on these previous investigations (Fig. 2).

The gasification experiments are conducted in an electrically heated furnace including a high-density alumina tube to prevent reactions of the tube walls with the released species. The sample boat was fixed on a ceramic rod, inserted into the preheated furnace and kept there for varying retention times from $10 \mathrm{~s}$ to $50 \mathrm{~s}$. The temperature was adjusted to $1400{ }^{\circ} \mathrm{C}$ in the reaction zone for all samples investigated in this study. Furthermore, a continuous gas flow of $20 \% \mathrm{CO}_{2}$ and $80 \%$ He was realized corresponding with $0.6 \mathrm{~L} / \mathrm{min} \mathrm{CO}_{2}$ and $2.4 \mathrm{~L} / \mathrm{min} \mathrm{He}$.

\subsection{Analysis of the gasified char}

The chemical analysis of the gasified solids was conducted by the Central Division of Chemical Analysis (Forschungszentrum Jülich). Changes of the chemical composition of each sample between the initial char and the residual char after gasification at varying retention times were analyzed and presented. The results were normalized by the content of $\mathrm{Ca}$, which is abundant in all samples and released in negligible amounts into the gas.

Additionally, mineral phases of the initial and gasified char were characterized by powder X-Ray-Diffraction (XRD). The high content of amorphous carbon in the sample leads to a high background in the XRDdiffractrograms and mineral phases with minor X-ray reflexes (e.g. silicates) were overlaid. Therefore, identification was restricted to semiqualitative results, which describe the relative amount of the main mineral phases. Although the conventional oxidation of ash for analysis would minimize the background in the spectra, the method is not suitable in this case because it may change the phase content.

Scanning electron microscopy (SEM) was conducted at a voltage of 7 $\mathrm{kV}$. The integrated EDX-detector enabled the local determination of the chemical composition. The distribution of inorganic components in the char was observed and differentiated between the retention times of the samples in the furnace. The samples were dried at $250{ }^{\circ} \mathrm{C}$ and coated with Ir before SEM analysis.

\subsection{Gas analysis (MBMS)}

MBMS-analysis was used to determine the composition of the evolving gas phase during the gasification process. The inlet of the MBMS device is directly connected to the outlet of the alumina tube furnace. The gas phase enters the first vacuum chamber of the instrument through a $0.3 \mathrm{~mm}$ nozzle. After the two following vacuum chambers a pressure of $100 \mathrm{nPa}$ is reached and the gas phase is analyzed by mass spectrometry. The detailed setup of the MBMS is described in Blasing et al. $[17,18]$. In this study, $\mathrm{CO} / \mathrm{CO}_{2}$ and $\mathrm{K}$ as main fragment of potassium species was qualitatively and semi-quantitatively measured. The reduction of $\mathrm{CO}_{2}$ by the glycol and carbon of the char during the reaction results in the formation of $\mathrm{CO}$ [23]. Thus, the start and the end of reaction of the glycol and char can be identified. The kinetics of the reactions of the ash components are recorded by the volatilized $\mathrm{K}$ in the gas phase.

\section{Theory}

The viscosity of biomass slags is strongly dependent on the incorporation of alkaline metals ( $\mathrm{Na}, \mathrm{K}$ ) [24]. Because alkaline metals are volatile at high temperatures, alkali fractionation is an influencing 


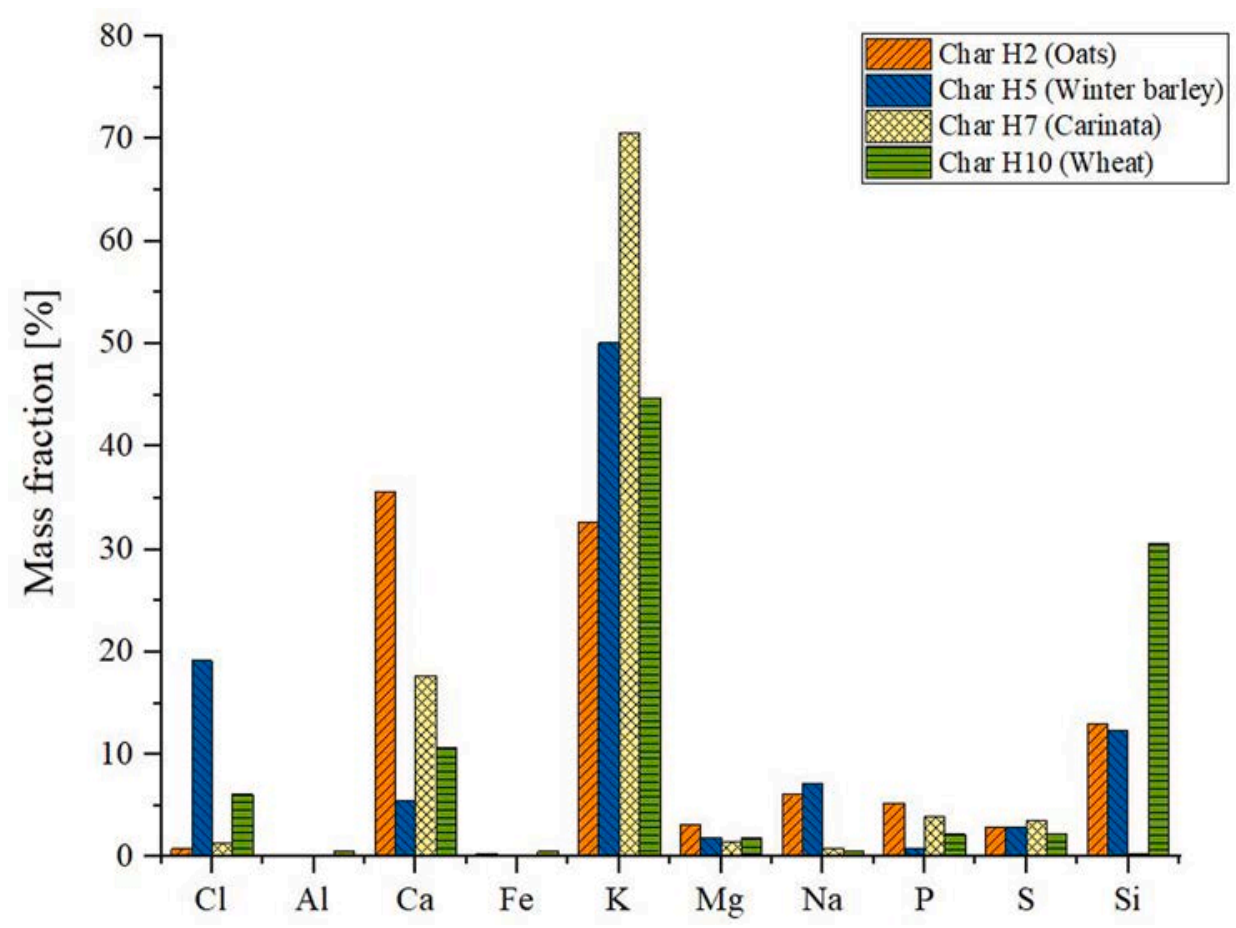

Fig. 1. Ash composition of the char samples (oxygen free composition calculated to 100 mass-\%).

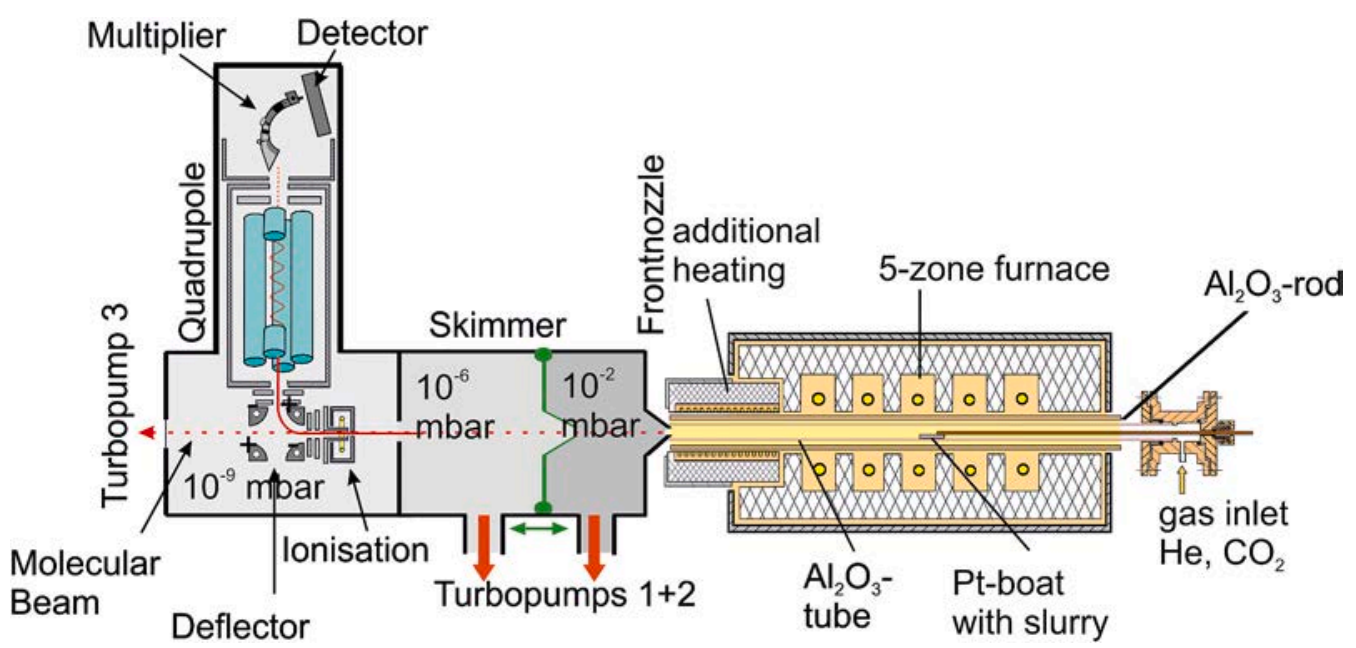

Fig. 2. Schematic drawing of the MBMS instrument.

process to the slag viscosity [25-30]. In straw biomass, $\mathrm{K}$ is the main alkali metal in the organic matrix and in inorganic salts such as $\mathrm{KCl}$ or $\mathrm{K}_{2} \mathrm{CO}_{3}$ [16,31-34]. Previous studies estimate that $<20 \%$ of $\mathrm{K}$ are released at temperatures $<700{ }^{\circ} \mathrm{C}$ as $\mathrm{KOH}$ or in combination with tars from organic bonded $\mathrm{K}$ in the straw matrix [35,36]. Inorganic salts are stable below $700{ }^{\circ} \mathrm{C}[26,31,32]$. In the temperature range of $700-900{ }^{\circ} \mathrm{C}$ evaporated $\mathrm{K}$ is attributed to the decomposition of $\mathrm{KCl}, \mathrm{K}_{2} \mathrm{CO}_{3}$ and remaining organic-bonded $\mathrm{K}$ in the char [31,37]. When temperatures exceed $900{ }^{\circ} \mathrm{C}, \mathrm{KOH}$ is formed by the reaction of $\mathrm{K}_{2} \mathrm{CO}_{3}$ with steam and released [32,37].

The remaining $\mathrm{K}$ at these temperatures is retained in silicates. Some silicates are already present in the raw straw or formed by ion exchange during the decomposition of K-salts at lower temperatures. The surrounding organic matrix can limit the formation of new inorganic compounds in char during gasification $[26,32]$.

A part of $\mathrm{S}$ is volatized at temperatures $<700{ }^{\circ} \mathrm{C}$. Another part remains in the char by forming $\mathrm{K}_{2} \mathrm{SO}_{4}$ [32]. At temperatures $>1000{ }^{\circ} \mathrm{C}$ sulfates start to evaporate. At reducing conditions, the decomposition temperature shifts below $500{ }^{\circ} \mathrm{C}[37,38]$.

Due to the abundance of $\mathrm{KCl}$ in straw biomass the release pathway of $\mathrm{Cl}$ also influences the fractionation of $\mathrm{K}$. While $40-60 \% \mathrm{Cl}$ evaporates at temperatures below $700{ }^{\circ} \mathrm{C}[26,31,32],<20 \% \mathrm{~K}$ is released in this temperature regime. The released $\mathrm{Cl}$ can originate from oxygen-rich, functional groups of organic and inorganic compounds and forms $\mathrm{HCl}$ in the gas phase. At temperature above $700{ }^{\circ} \mathrm{C}$ the remaining amount of $\mathrm{Cl}$ is released from decomposing $\mathrm{KCl}[26,32]$. The reaction pathways are influenced by the composition of the surrounding gas atmosphere, the residence times and composition, the particle size and porosity of the ash particles [16,31,37].

The hot gas phase can be online monitored by using molecular beam mass spectrometry (MBMS). Recent studies focus on the different release of inorganics from coal, straw, and blends under combustion or 
gasification related atmospheres [17,18,39,40]. Devolatilization and char reactions were distinguished at several times. Devolatilization is characterized by relatively short-term, intensive reactions and is related to pyrolysis or gasification conditions in these investigations. Char reactions take place after the devolatilization with lower intensity in the MS-spectra and are even in gasification related experiments, where oxygen is the gasification agent, similar to combustion-like conditions under experimental conditions [18]. To minimize oxygen excess during char reactions, investigations that are more recent used $\mathrm{CO}_{2}$ as gasification agent as it is very common in investigations on char conversion kinetics [23].

Whereas most recent studies investigate the conversion of solid straw or coal in combustion or inert pyrolysis environment at temperatures up to $1000{ }^{\circ} \mathrm{C}[26,31,34,35]$, the studies in gasification environment were not focused on straw biomass $[16,41,42]$. The actual study fills this gap by investigating the release behavior of a suspension consisting of solid straw char and liquid glycol under gasification related conditions. The wide diversity of straw composition is considered by different chemical composition of ash-forming components such as $\mathrm{Si}, \mathrm{K}$ and $\mathrm{Ca}$. The reaction pathways and kinetics of the release were investigated by varying residence times under constant temperatures around $1400{ }^{\circ} \mathrm{C}$. The gained qualitative information of this study will provide knowledge about the chemical fractionation processes in the conversion zone of an entrained-flow gasifier. This knowledge will be used to develop and improve a flowsheet model of the gasification process, which will provide a calculated chemical composition of the slag at the gasifier wall. This chemical composition will be used for further viscosity determinations.

\section{Results}

\subsection{Release behavior}

The four investigated straw samples (H2, H5, H7 and H10) show similar behavior during the release experiments. The glycol evaporates and reacts immediately with $\mathrm{CO}_{2}$ when the sample enters the high

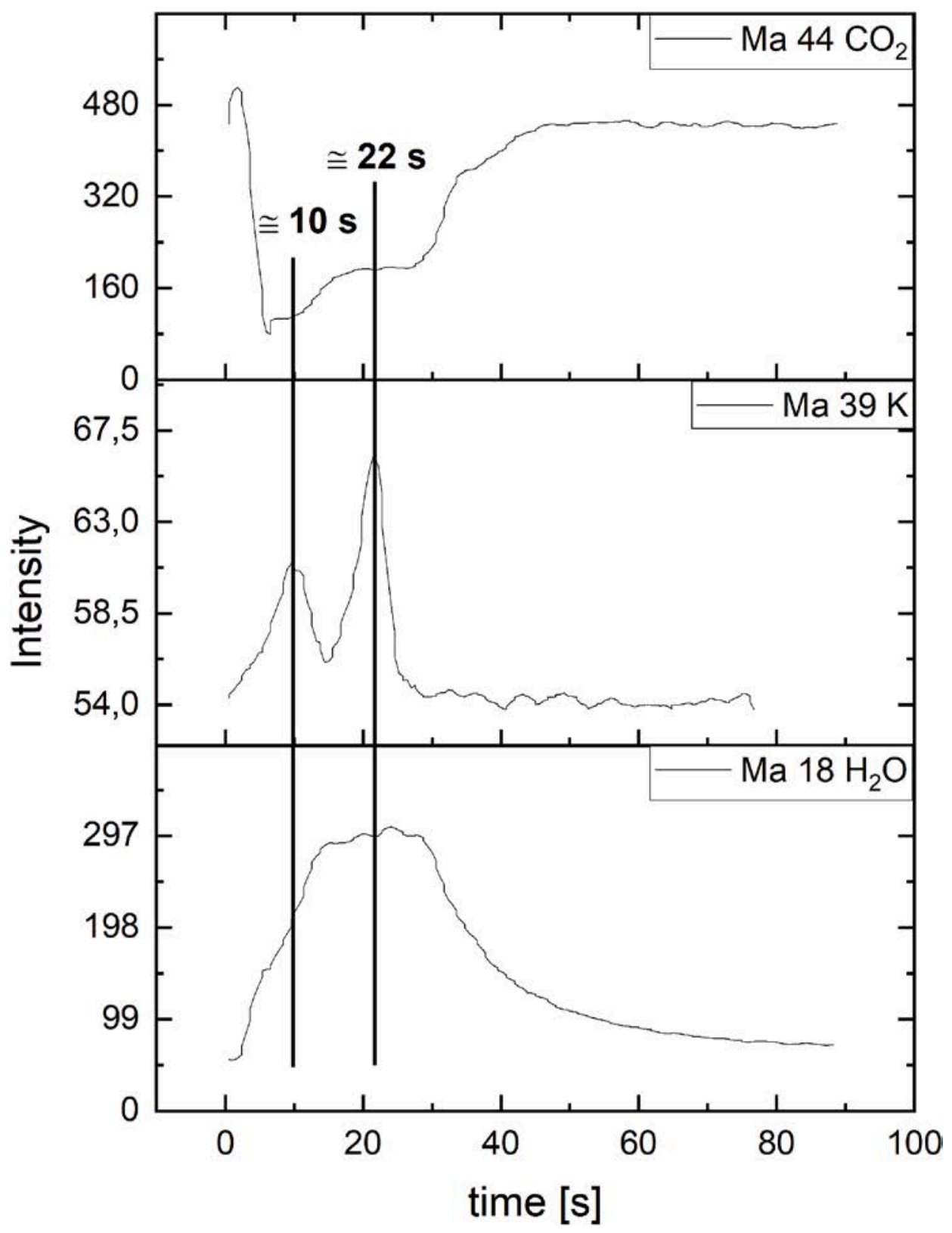

Fig. 3. MBMS-spectra of CO2 (Mass 44), K (Mass 39) and H2O (Mass 18) depending on time during the gasification of the sample H10. 
temperature zone of the furnace. The reaction leads to a steep decrease of $\mathrm{CO}_{2}$ and an increase of $\mathrm{H}_{2} \mathrm{O}$ in the MBMS-spectrum during the first 10 $\mathrm{s}$ (Fig. 3). After ca. $15 \mathrm{~s}$ the amount of $\mathrm{CO}_{2}$ increases in the gas because most of the glycol and its containing carbon have reacted. Since the char reacts much slower with $\mathrm{CO}_{2}$ than the glycol, the $\mathrm{CO}_{2}$ concentration during char gasification is higher. As long as the volatile part of the char, which contains the hydrogen, is converted, the $\mathrm{H}_{2} \mathrm{O}$ concentration remains high. After ca. $30 \mathrm{~s}$ the reactivity of the residual char decreases slowly, therefore $\mathrm{CO}_{2}$ further increases and $\mathrm{H}_{2} \mathrm{O}$ decreases slowly. At the end of the measurement, the $\mathrm{CO}_{2}$ concentration has not reached the inlet concentration because the char is not completely converted at that time.

After ca. $12 \mathrm{~s}$ the first part of potassium is released, shown by an increase of K-content in the gas, indicating the beginning reactions of the solid char, which contains the potassium. Thus, the release of $\mathrm{K}$ starts $2 \mathrm{~s}$ after the vaporization and reaction of glycol characterized by the decrease of $\mathrm{CO}_{2}$ in the gas. Consequently, it can be assumed, that the surrounding glycol delays the reaction of the inorganic components. After $20 \mathrm{~s}$ a second significant amount of $\mathrm{K}$ is released during char gasification of the sample.

\subsection{Char characterization}

SEM-images confirm the presence of glycol after $10 \mathrm{~s}$ in the remaining char. The structures shown in Fig. 4 were caused by the suspension of glycol and char in the slurry. The glycol was evaporated during sample preparation directly before the SEM-analysis. The agglomerated inorganic particles remain from the initial structures and are observed in the SEM-images. After residence times longer than $10 \mathrm{~s}$ all glycol has reacted during the gasification and the suspension structures disappear.

The main ash components $\left(\mathrm{CaO}, \mathrm{K}_{2} \mathrm{O}\right.$ and $\left.\mathrm{SiO}_{2}\right)$ of the investigated chars are displayed in Fig. 5 . All four samples show a depletion of $\mathrm{K}_{2} \mathrm{O}$ after reaction at $1400^{\circ} \mathrm{C}$. The amount of released $\mathrm{K}$ changes between the residence times pointing out different reactions at certain stages of the gasification. A significant depletion of $\mathrm{K}$ takes already place in all samples after $10 \mathrm{~s}$ of gasification by evaporating the $\mathrm{K}$ from the sample surface. The MBMS spectrum confirms this result showing a strong Krelease after 10-15 s (Fig. 6).

Fig. 7 shows the mineral phases present in the chars after varies residence times determined qualitatively by XRD. It gives information on the association of ash components and their reactions during gasification. The samples $\mathrm{H} 2$ and $\mathrm{H} 7$ are characterized by high Ca-contents (Fig. 5). The $\mathrm{Ca}$ is primary associated with $\mathrm{CaCO}_{3}$ in the two samples, which is confirmed by the results in the overview of the XRD-results (Fig. 7). The decomposition of $\mathrm{CaCO}_{3}$ starts after $10 \mathrm{~s}$ and results in the intermediate formation of $\mathrm{CaO}$. At the same time, the atmosphere leads to the reduction of sulfates, such as $\mathrm{K}_{2} \mathrm{SO}_{4}$. The oxygen of these sulfates is reduced and the sulfur is retained in sulfides, such as $\mathrm{CaS}$ with the $\mathrm{Ca}$ of the $\mathrm{CaO}$.

Relevant amounts of K-phases were not identified by XRD in the initial char of $\mathrm{H} 2$ and $\mathrm{H} 7$ and might be incorporated in the C-matrix or in mineral phase with weak reflexes (e.g. silicates), which are overlaid by the x-ray amorphous carbon. The main difference between $\mathrm{H} 2$ and $\mathrm{H} 7$ is the higher K-content in $\mathrm{H7}$, which cannot be associated with $\mathrm{Si}, \mathrm{Cl}$ or $\mathrm{Ca}$ (ratio in Table 1). $\mathrm{K}$ in $\mathrm{H} 7$ might be incorporated in $\mathrm{K}_{2} \mathrm{SO}_{4}$ and char matrix while $\mathrm{K}$ in $\mathrm{H} 2$ can occur in silicates and with $\mathrm{Ca}$. Therefore, $\mathrm{H} 2$ is characterized by a significant K-loss after $10 \mathrm{~s}$ in comparison with $\mathrm{H7}$ (Fig. 5), which is also visible in the MBMS-spectrum of the gas output (Fig. 6).

The $\mathrm{K}$ remaining in the samples $\mathrm{H} 2$ and $\mathrm{H} 7$ forms K-carbonates after 20-30 s (Fig. 7). The $\mathrm{C}$ originates from the char matrix and from the decomposing $\mathrm{CaCO}_{3}$. The carbonates decompose with increasing retention time. The $\mathrm{Ca}$ remains as $\mathrm{CaO}$ or $\mathrm{CaS}$ in the char. The $\mathrm{K}$ is released continuously into the gas phase in $\mathrm{H} 2$. The low amount of $\mathrm{Si}$ in $\mathrm{H} 7$ cannot keep the $\mathrm{K}$ in the sample. Additionally, the higher amount of $\mathrm{Ca}$ is preferred to be incorporated in silicates and replace $\mathrm{K}$ from the stable phases [43]. Therefore, the strong K-release occurs after 40 during gasification of $\mathrm{H7}$ and can be assigned to decomposition of intermediate formed K-carbonates (Fig. 5).

The untreated samples $\mathrm{H} 5$ and $\mathrm{H} 10$ contain significant amounts of $\mathrm{K}$ and $\mathrm{Cl}$, which are incorporated in $\mathrm{KCl}$ (Fig. 7). In $\mathrm{H} 5$ the $\mathrm{K} / \mathrm{Cl}$ ratio is lower than in $\mathrm{H} 10$, which indicates that more $\mathrm{Cl}$ is associated with $\mathrm{KCl}$

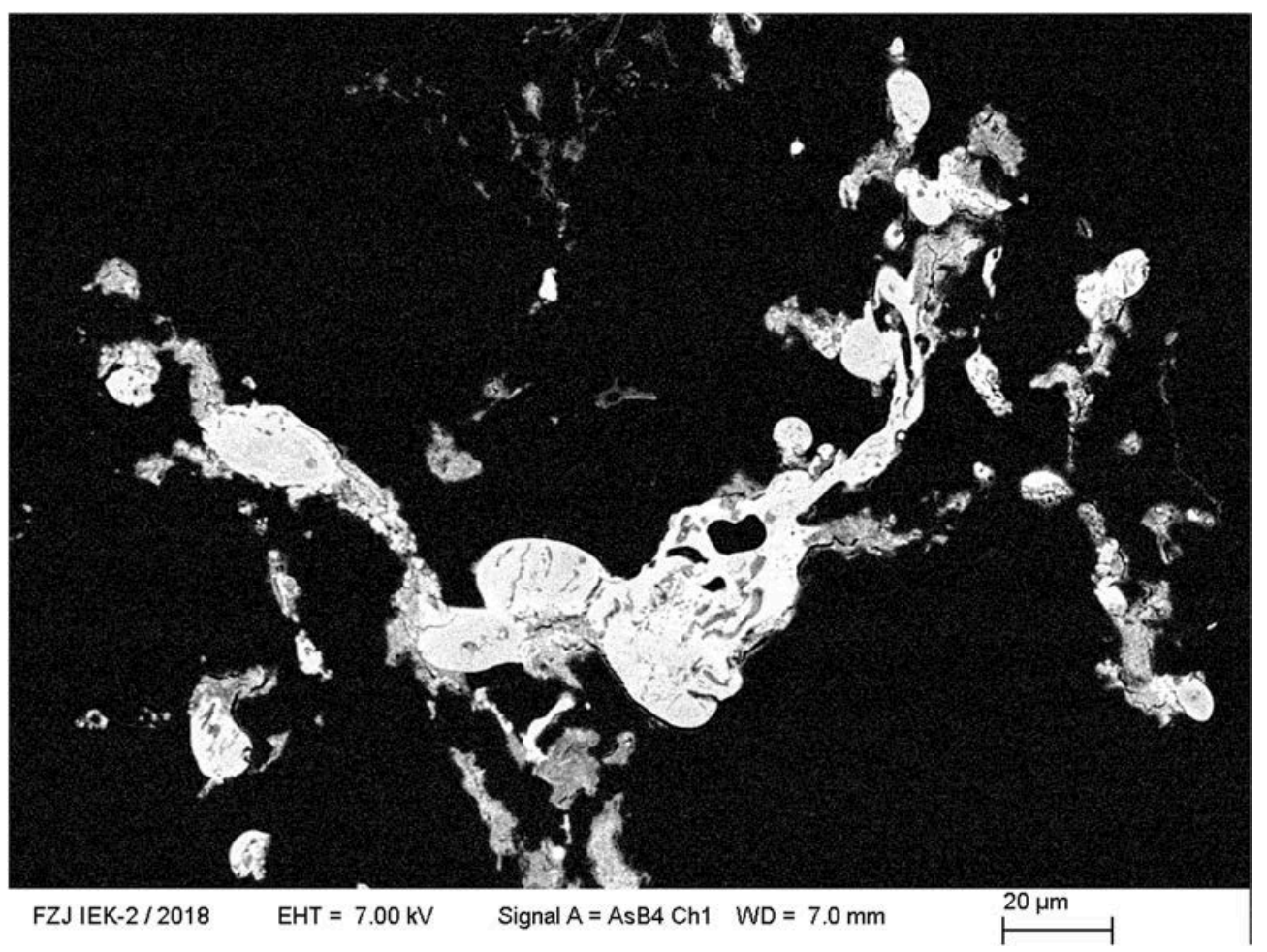

Fig. 4. Structures of suspension consisting of remaining ash constituents in the char of H5 after 10s in SEM-images (BSE). 


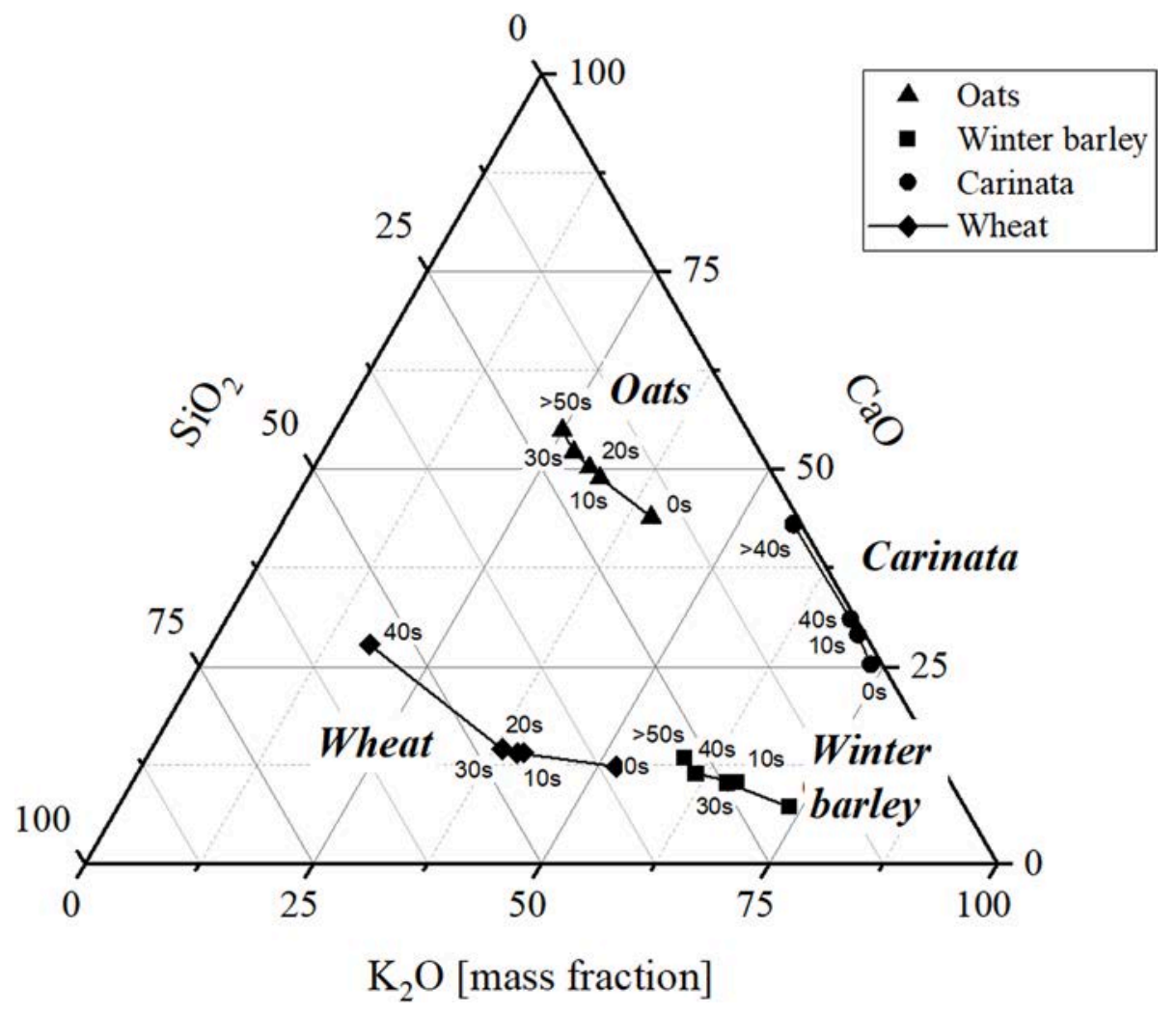

Fig. 5. Concentration of the three main ash components in the char of the four straw samples H2, H5, H7 and H10 after various residence times.

(Table 1). The vaporization of $\mathrm{KCl}$ results in strong decrease of $\mathrm{Cl}$ and $\mathrm{K}$ in several stages after $10 \mathrm{~s}, 40 \mathrm{~s}$ and $50 \mathrm{~s}$ (Fig. 8). A similar decrease of $\mathrm{K}$ was also observed in analysis of $\mathrm{H} 10$ and is confirmed with its MBMS spectrum (Fig. 3). The $\mathrm{K}$ in $\mathrm{H} 5$ is also associated with $\mathrm{K}_{2} \mathrm{SO}_{4}$. The decomposition of this phase results in the formation of $\mathrm{CaS}$, similar to the process in $\mathrm{H} 2$ and $\mathrm{H} 7 . \mathrm{H} 10$ has the highest Si-content of the samples. The formation of K-carbonates was not observed for this sample, which may indicate the preferred incorporation of $\mathrm{K}$ in silicates instead of carbonates (Table 1). However, most $\mathrm{K}$ is still present as $\mathrm{KCl}$ until $30 \mathrm{~s}$ and is then released directly into the gas phase instead of being retained in the sample to form K-silicates (Fig. 7). Therefore, pure $\mathrm{SiO}_{2}$ is still present in $\mathrm{H} 10$ after $40 \mathrm{~s}$ retention.

Most of the inorganic components are distributed in small aggregates in the char matrix containing different elements ( $\mathrm{Ca}, \mathrm{Mg}, \mathrm{Na}, \mathrm{K}, \mathrm{Si}, \mathrm{S}$, etc.). The random distribution of these aggregates results in discontinuous reaction pathways during the gasification. Thus, the location of the inorganic particles has a significant influence to the reaction kinetics. A part of Si occurs in separate grains (Fig. 9A). Furthermore, the physical structure of the straw remains visible. The plant species of $\mathrm{H} 5$ and $\mathrm{H} 10$ incorporate high $\mathrm{Si}$-amounts in layers around their structure which can be seen in Fig. 9A/B after $40 \mathrm{~s}$ retention time. EDX analysis of these could show an incorporation of $\mathrm{Ca}, \mathrm{K}$ and $\mathrm{Na}$ in these Si-layers with increasing residence times. The presence of pure $\mathrm{SiO}_{2}$ in XRD and SEM after retention of $40 \mathrm{~s}$ indicates, that this incorporation is not complete after long residence times and might be inhibited caused by the surrounding C-matrix.

\section{Discussion}

\subsection{Devolatilization and char reactions}

According to Blasing et al. [18] the gasification process can be divided into devolatilization and char reactions. Devolatilization is the dominating process after $10 \mathrm{~s}$ retention time in this study. Glycol and volatile components like $\mathrm{K}$ at the char surface are instantly evaporated which is shown in the MBMS-spectra. The endothermal evaporation of the surrounding glycol results in a cooling of the solid particles and delays the reactions in the char particles. After $20 \mathrm{~s}$ char reactions have a stronger influence on the reaction pathways of the samples and the gas phase composition. Mineral phases in the char decompose and form new phases which incorporate and release volatiles. The diffusion of the elements can be suppressed by the surrounding matrix [38]. Therefore, the release pathways are highly depended on the chemical composition and the distribution of inorganic components in the straw or char samples.

\subsection{Potassium}

In the initial samples, $\mathrm{K}$ is incorporated in the identified phases $\mathrm{KCl}$ and $\mathrm{K}_{2} \mathrm{SO}_{4}$ and some overlaid and unidentified phases. The presence of $\mathrm{Cl}$ in $\mathrm{H} 5$ and $\mathrm{H} 10$ indicates the occurrence of $\mathrm{KCl}$, which is a major source for release of $\mathrm{K}$ in these samples, although the time of $\mathrm{KCl}$ vaporization is different for the two samples. The mineral vaporizes at $700{ }^{\circ} \mathrm{C}[31,32,35,36]$, which is achieved fast at the surface of the sample at temperatures of $1400{ }^{\circ} \mathrm{C}$. Potential reaction partners cannot retain $\mathrm{K}$ in the char because the still existing C-Matrix inhibits the incorporation and the inorganic partners are randomly distributed. Therefore, a significant amount of $\mathrm{K}$ evaporates as $\mathrm{KOH}(\mathrm{g})$ or $\mathrm{K}(\mathrm{g})$ during the first $10 \mathrm{~s}$ $[43,44]$ and exceeds the amount of $\mathrm{K}$ predicted by the thermodynamic equilibrium calculation.

Another part of $\mathrm{K}$ remains as $\mathrm{KCl}$ in the solid char until 30 s retention time (Fig. 7), although the salt should vaporize completely at the temperatures of $1400{ }^{\circ} \mathrm{C}$. The temperature gradient delays inorganic reactions to the center of the single char particles and of the whole granulate. The effect is supported by the inhibition of inorganic diffusion processes by the surrounding C-matrix [31,32,37]. K-carbonates are formed as intermediate products, which are characterized by higher vaporization temperatures than $\mathrm{KCl}$. As a result, the carbonates occur at 


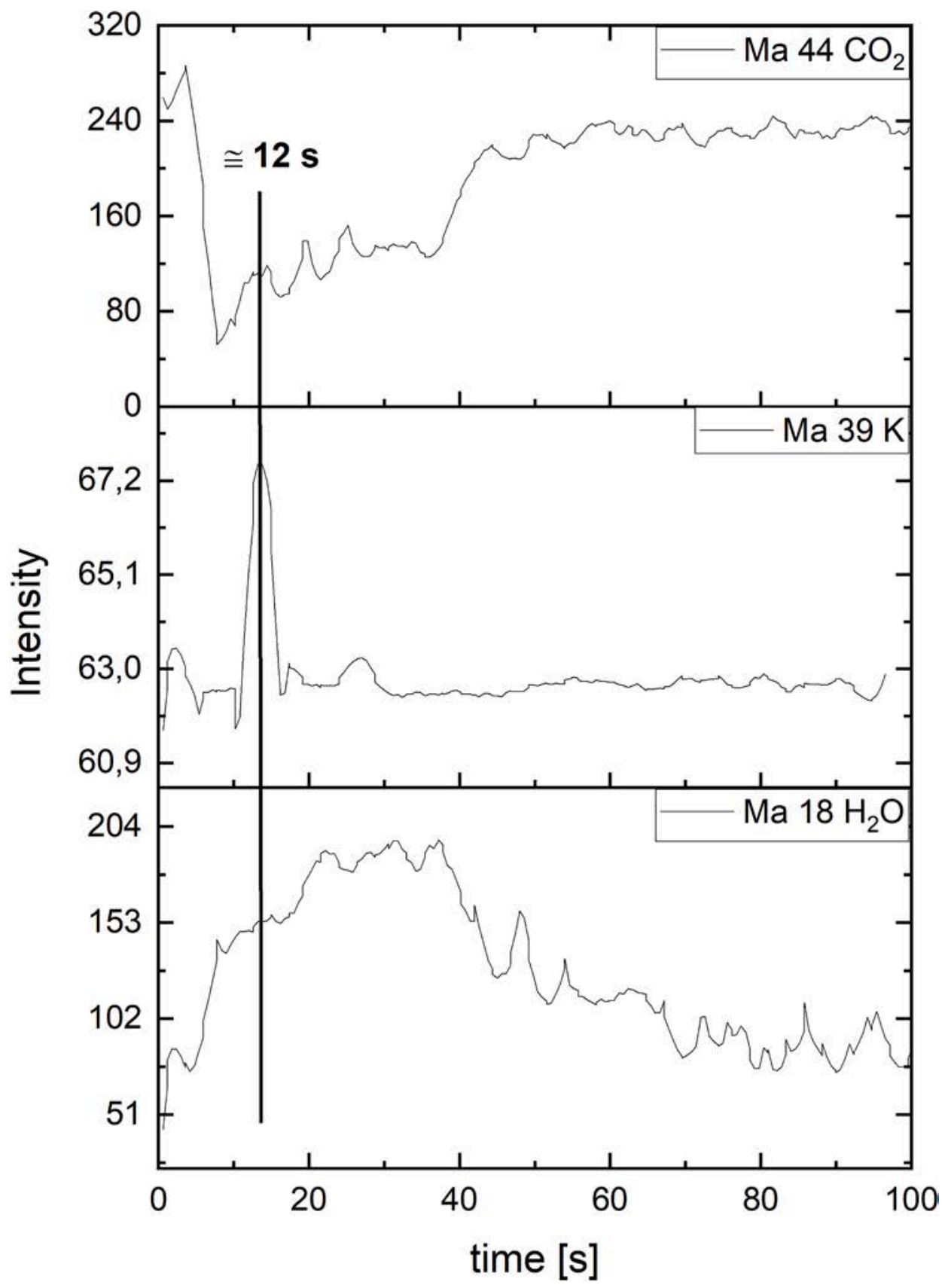

Fig. 6. MS-spectrum of $\mathrm{CO} 2$ (Mass 44), K (Mass 39) and H2O (Mass 18) depending on time during the gasification of the sample H2.

higher residence times up to $50 \mathrm{~s}$ and keep additional $\mathrm{K}$ in the sample. The formation of K-carbonates is connected with silica [26,32]. In sample $\mathrm{H} 10$ with high amount of silica, the $\mathrm{K}$ tend to be incorporated in silicates instead of forming carbonates which correspond with the literature $[32,33,38]$. More stable silicates fix the $\mathrm{K}$ in their structure over long retention times.

\subsection{Silica}

Silicates might occur in the initial char, but identification by XRD is limited due to the background caused by the high C-content. The decomposition of salts and carbonates release $\mathrm{K}$ and $\mathrm{Ca}$. A certain amount is incorporated in silicates and remains in the char at long residence times during the experiment $[37,45,46]$. Another silica phase is sand, which most likely entered the sample during sample collection. The grains were identified in the SEM.
The incorporation of $\mathrm{K}$ in the $\mathrm{Si}$ layer structures, which surround the char particles, was observed in this study according to Knudsen et al. [32]. The significant amount of $\mathrm{Si}$ will result in the formation of silicates, which incorporate $\mathrm{K}, \mathrm{Ca}$ and inorganic components by substitution [43, 47]. The concentration of $\mathrm{Si}$ in these layers at the edge of the char particles delays the formation of these silicates because of the longer migration paths. Additionally, $\mathrm{K}$ can be replaced by more stable $\mathrm{Ca}$, which increases the release of $\mathrm{K}$ into the gas phase. The occurrence of $\mathrm{Si}$ in straw influences the release behavior significantly because available $\mathrm{K}$ prefers to be incorporated in high temperature-stable silicates.

\subsection{Application to the condition in the bioliq ${ }^{\circledR}$-gasifier}

The atomized fuel in the bioliq ${ }^{\circledR}$-gasification has a reactive surface in the order of magnitudes higher than the samples of the present experiments. Therefore, reactions will proceed much faster in the real gasifier 


\begin{tabular}{|c|c|c|c|c|c|c|}
\hline & 0s & $10 \mathrm{~s}$ & $20 \mathrm{~s}$ & $30 \mathrm{~s}$ & 40s & $>50 \mathrm{~s}$ \\
\hline \multirow{3}{*}{ H2 } & \multirow{3}{*}{$\mathrm{CaCO}_{3}$} & & & $\mathrm{CaO}$ & & \multirow[b]{2}{*}{$\mathrm{CaS}$} \\
\hline & & & & & & \\
\hline & & & & & $\mathrm{K}\left(\mathrm{HCO}_{3}\right)$ & \\
\hline \multirow{3}{*}{ H5 } & & $\mathrm{KCl}$ & & & \multirow[b]{2}{*}{$\mathrm{CaS}$} & \\
\hline & $\mathrm{K}, \mathrm{SO}$ & & & & & \\
\hline & & & & & & $\mathrm{K}_{2} \mathrm{CO}_{3}$ \\
\hline \multirow{4}{*}{ H7 } & $\mathrm{K}_{2} \mathrm{SO}_{4}$ & & & & \multirow[b]{2}{*}{$\mathrm{CaO}$} & \\
\hline & & $\mathrm{CaCO}_{3}$ & & & & \\
\hline & & $\mathrm{K}_{2} \mathrm{Ca}\left(\mathrm{CO}_{3}\right)_{2}$ & & $\mathrm{CaS}$ & & \\
\hline & & & & $\overline{\mathrm{K}\left(\mathrm{HCO}_{3}\right)}$ & & \\
\hline \multirow{3}{*}{ H10 } & & & $\mathrm{SiO}_{2}$ & & & \\
\hline & & $\mathrm{KCl}$ & & & \multirow[b]{2}{*}{$\mathrm{CaS}$} & \\
\hline & & & & & & \\
\hline
\end{tabular}

Fig. 7. Phase distribution in the chars of the four straw samples H2, H5, H7, and H10 after varied residence times determined qualitatively by XRD for each sample.

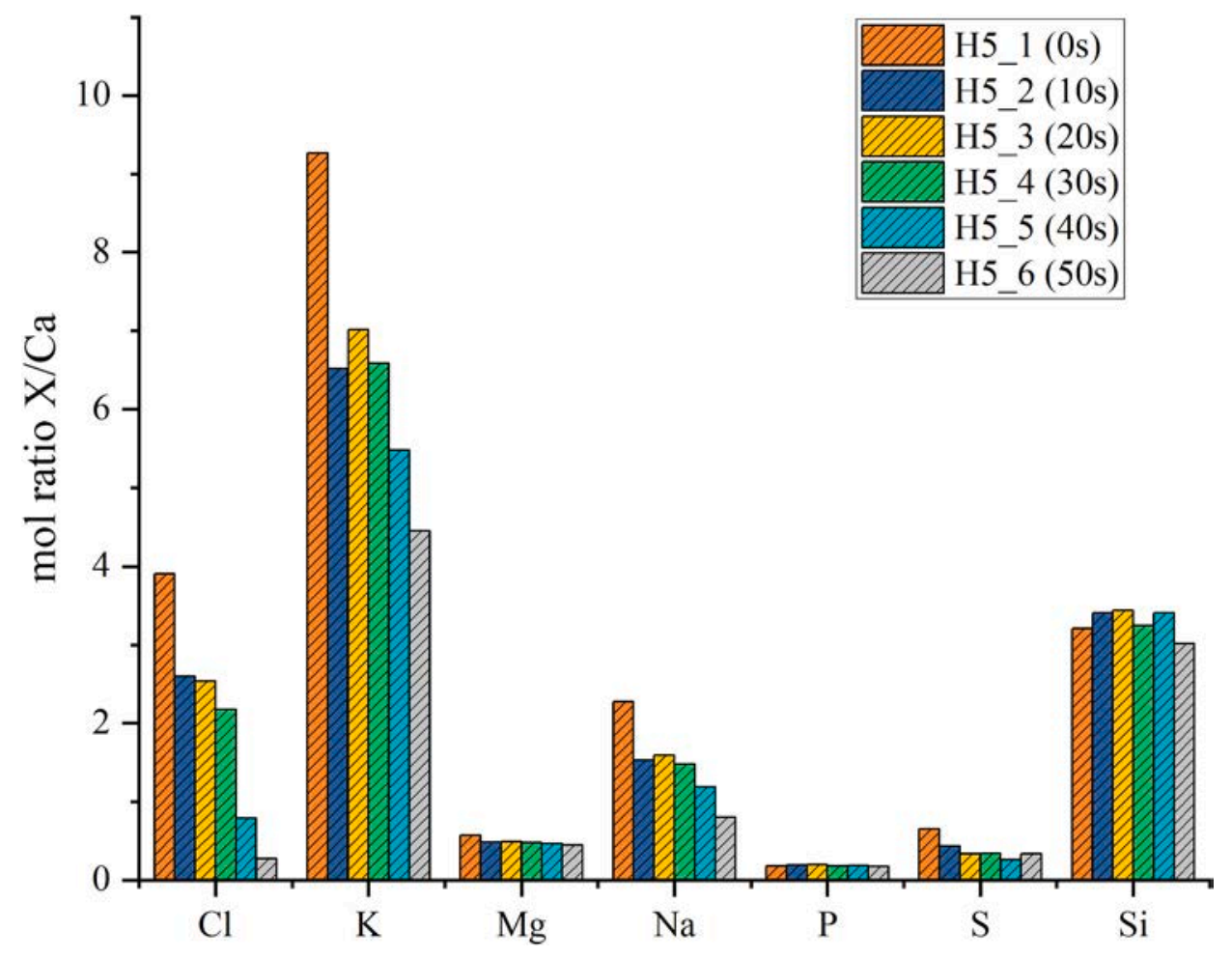

Fig. 8. Chemical composition of char H5 after various residence times and divided by the Ca-content.

than in the present batch-type experiments. However, the residence times in the gasifier of $2-6 \mathrm{~s}$ are also significantly shorter [48]. Thus, the principal impact of the effects on the inorganic compounds will be similar.
The liquid phase is volatized in the zone of droplet evaporation in the gasifier. The endothermic reaction implies a cooling effect shown in the experiment and also appears in the gasifier causing an average droplet temperature in the gasifier around $400{ }^{\circ} \mathrm{C}$ [7]. Consequently, the delay 

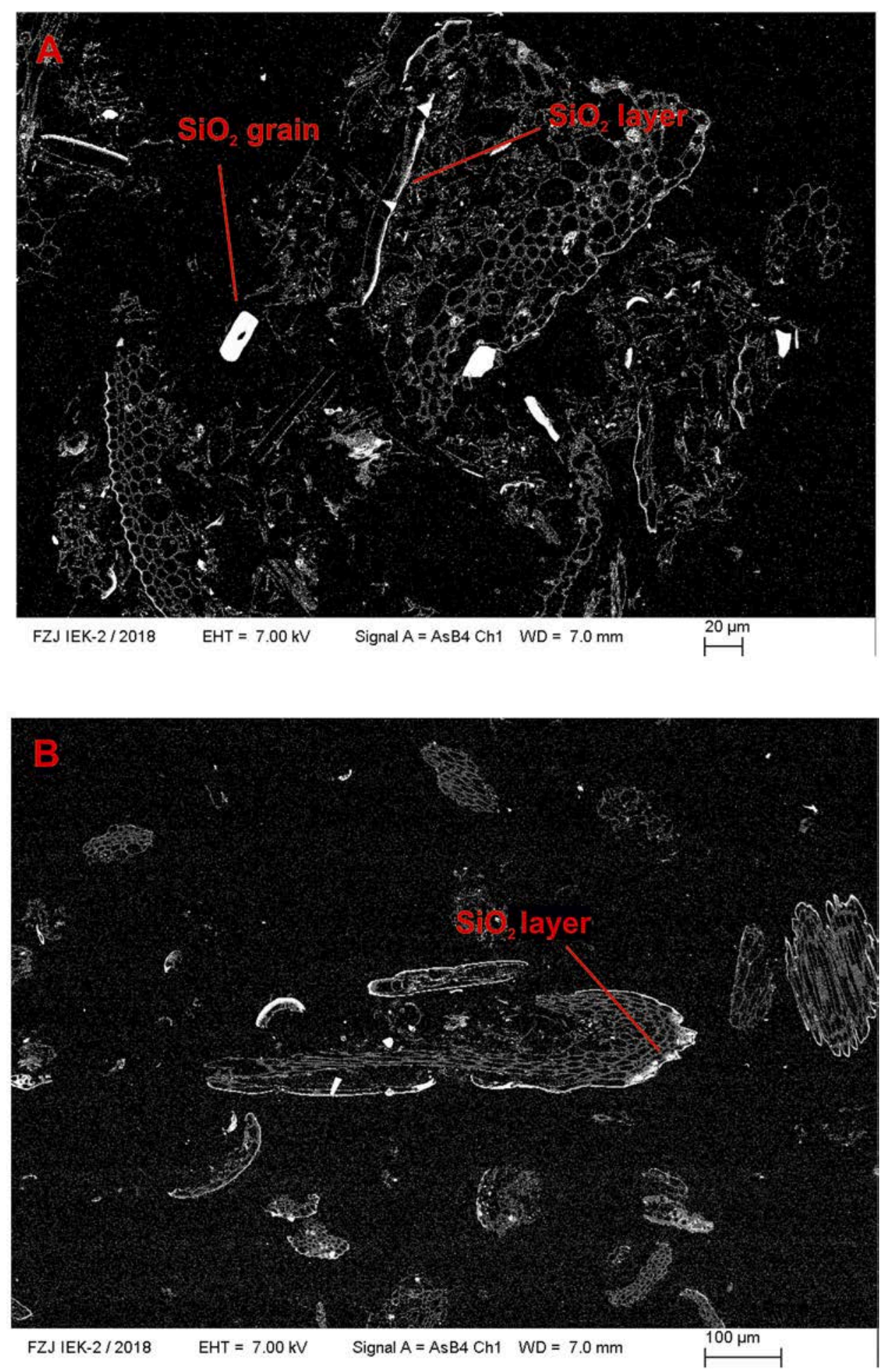

Fig. 9. SEM-Images (BSE) of H5 (A) and H10 (B) after $40 \mathrm{~s}$ residence time.

of inorganic reactions is also present in the gasifier, although it appears in a smaller time scale.

After the volatilization of the ethylenglycol, a part of $\mathrm{K}$ is released from the char surface according to the K-release after $10 \mathrm{~s}$ in the experiments of this study. As a result, the volatized $\mathrm{K}$ is not available to influence the viscosity at the reactor wall, because the released $\mathrm{K}$ immediately leaves the reactor with the gas phase.

The C-matrix still existing after $40 \mathrm{~s}$ in the experiment shows the impact of the C-matrix to inorganic reactions during char gasification. The short residence times in the flame of the gasifier also imply an incomplete conversion of the char particles resulting in a C-matrix, which surrounds the particles in the gasifier for a certain time. According to the results of this study, the C-matrix will imply reducing conditions to the inorganic components and inhibits the diffusion of the inorganic components in the zones of the gasifier. Thus, intermediate products, e.g. K-carbonates, are formed during the gasification process and will reach the reactor wall influencing the chemical composition of the slag, e.g. by bringing additional $\mathrm{K}$ into this system. Additionally, the carbonates can form molten salts at the reactor wall and influence the flow behavior of the slag, which is dominated by oxide melts containing 
silica [43]. The degree of char conversion is depending on the chemical composition, the distribution of the inorganics in the ash and surrounding the liquid phase.

\section{Conclusions}

Inorganic components are influencing the viscosity of the evolving slag at the inner wall of the gasifier significantly. They are present in the char of the feedstock and thus surrounded by a C-matrix. Due to the short residence time of the feedstock in entrained-flow gasification, this C-matrix remains present around the inorganic particles in the char over several zones in the gasifier. This study shows a delay of inorganic reactions caused by the C-matrix and the impact to the reaction condition in the char particles. Thus, the $\mathrm{C}$ reduces the inorganic oxides resulting in oxygen-free inorganic compounds like CaS.

The solid char is surrounded by liquid ethylenglycol. Its vaporization is an endothermic reaction, taking place before the reaction of the char and cooling down the temperature at the char particles. Consequently, the presence of the liquid phase delays inorganic reactions in the char by $2 \mathrm{~s}$ in the experiments. In the gasifier, the delay is shorter but still has to be considered due to the shorter residence times.

The amount of $\mathrm{K}$ will have a strong influence on the flow-behavior of the slag during the gasification process. The network modifier $\mathrm{K}$ is a main inorganic component in straw biomass and will decrease the viscosity of the slag in the entrained flow gasifier. In addition, the alkaline metal is partly released into the gas phase before reaching the gasifier wall, where the slag is formed. In this study, several stages of K-release were defined referring to the accompanying components e.g. Si and Ca and the conditions of reaction.

The first release stage occurs after $10 \mathrm{~s}$ in all samples of this study and is assigned to the direct release of $\mathrm{K}$ from the samples surface. During this process, additional $\mathrm{K}$ is released because inorganic reaction partners are not available due to separation by the surrounding C-matrix. This effect is strong at the surface of the sample because temperature conditions change fast from room temperature to $1400{ }^{\circ} \mathrm{C}$ there and minimize the chance to reach reaction partners, which keep $\mathrm{K}$ in the char. The additionally released $\mathrm{K}$ is thus not available for influencing the viscosity at the gasifier wall.

The following stages of release are depended on the bonding conditions of accompanying components and appear different in the four investigated samples. While for the sample $\mathrm{H} 2$ the $\mathrm{K}$ is released continuously after the surface reaction, the other three samples show a second significant release between $20 \mathrm{~s}$ and $40 \mathrm{~s}$. The differences of the K-release are referred to the formation of different intermediate phases due to the varying chemical composition. Additionally, the temperature gradient in the sample and the surrounding C-matrix delay the reactions of inorganic constituents and support the formation the intermediate phases. The intermediate phases can incorporate additional $\mathrm{K}$ in the char, which upon reaching the gasifier wall increase the K-content of the slag. The limiting factor is the local availability of reaction partners, which is depended on the randomly distributed inorganic aggregates in the char samples.

\section{Acknowledgement}

The authors gratefully acknowledge the financial support by the Helmholtz Association of German Research Centres (HGF) in the frame of the Helmholtz Virtual Institute for gasification Technology HVIGasTech (VH-VI-429).

\section{References}

[1] N. Dahmen, J. Abeln, M. Eberhard, T. Kolb, H. Leibold, J. Sauer, D. Stapf, B. Zimmerlin, The bioliq process for producing synthetic transportation fuels, WIREs Energy Environ 6 (3) (2016) 1-10.

[2] N. Dahmen, E. Dinjus, Synthetische Chemieprodukte und Kraftstoffe aus Biomasse, Chem. Ing. Tech. 82 (No.8) (2010) 1147-1152.
[3] T. Nicoleit, N. Dahmen, J. Sauer, Production and Storage und Gasifiable Slurries Based on Flash-Pyrolyzed Straw, Energy Technology, 2016, pp. 211-229.

[4] Q. Fradet, M. Braun-Unkhoff, U. Riedel, A sectional approach for the entrainedflow gasification of slurry fuels, Energy Fuel. 32 (12) (2018) 12532-12544.

[5] M. Eberhard, U. Santo, D. Boning, H. Schmid, B. Michelfelder, B. Zimmerlin, A. Günther, P. Weigand, M. Müller-Hagedorn, D. Stapf, T. Kolb, Der bioliq(®Flugstromvergaser - ein Baustein der Energiewende, Chem. Ing. Tech. 90 (1-2) (2018) 85-98.

[6] T. Kolb, M. Eberhard, N. Dahmen, H. Leibold, M. Neuberger, J. Sauer, H. Seifert, B. Zimmerlin, Btl - the bioliq process at KIT, DGKM Tagungsbericht 2013-2 (2013) 81-87.

[7] T. Kolb, M. Aigner, R. Kneer, M. Müller, R. Weber, N. Djordjevic, Tackling the challenges in modelling entrained-flow gasification of low-grade feedstock, J. Energy Inst. 89 (4) (2016) 485-503.

[8] C. Higman, M. van der Burgt, Gasification, Elsevier Science, Burlington, 2003.

[9] S. Arvelakis, F.J. Frandsen, B. Folkedahl, J. Hurley, Viscosity of ashes from energy production and municipal solid waste handling: a comparative study between two different experimental setups, Energy Fuel. 22 (5) (2008) 2948-2954.

[10] M.W. Nichols, A.P. Lingras, D. Apelian, Viscosity characteristics of commercial fluxes for bottom-poured ingots, Metall. Slags Fluxes, Int. Symp., Proc. 2nd (1984) 235-251.

[11] S. Arvelakis, F.J. Frandsen, K. Dam-Johansen, Viscosity characteristics of ashes from the Co-firing of coal and biomass, Proceedings of the International Technical Conference on Coal Utilization \& Fuel Systems (2005) 1215-1225.

[12] J. Gao, G. Wen, T. Huang, P. Tang, Q. Liu, Effects of the composition on the structure and viscosity of the CaO-SiO2-based mold flux, J. Non-Cryst. Solids 435 (2016) 33-39.

[13] S. Fleck, U. Santo, C. Hotz, T. Jakobs, G. Eckel, M. Mancini, R. Weber, T. Kolb, Entrained flow gasification Part 1: gasification of glycol in an atmospheric-pressure experimental rig, Fuel 217 (2018) 306-319.

[14] M. Mancini, R. Weber, P. Weigand, W. Leuckel, T. Kolb, Design of the entrained flow reactor for gasification of biomass based slurry, VDI-Berichte, Verbrennung und Feuerung : 26.Deutscher Flammentag, 2013, pp. 625-634.

[15] M. Mancini, M. Alberti, M. Dammann, U. Santo, G. Eckel, T. Kolb, R. Weber, Entrained flow gasification. Part 2: mathematical modeling of the gasifier using RANS method, Fuel 225 (2018) 596-611.

[16] P.A. Tchoffor, F. Moradian, A. Pettersson, K.O. Davidsson, H. Thunman, Influence of fuel ash characteristics on the release of potassium, chlorine, and sulfur from biomass fuels under steam-fluidized bed gasification conditions, Energy Fuel. 30 (12) (2016) 10435-10442.

[17] M. Müller, K.-J. Wolf, A. Smeda, K. Hilpert, Release of $\mathrm{K}, \mathrm{Cl}$, and S species during Co-combustion of coal and straw, Energy Fuel. 20 (4) (2006) 1444-1449.

[18] M. Blasing, N.B.A. Hasir, M. Müller, Release of inorganic elements from gasification and Co-gasification of coal with miscanthus, straw, and wood at high temperature, Energy Fuel. 29 (11) (2015) 7386-7394.

[19] K.J. Wolf, M. Müller, K. Hilpert, L. Singheiser, Alkali sorption in second-generation pressurized fluidized-bed combustion, Energy Fuel. 18 (6) (2004) 1841-1850.

[20] N. Dahmen, J. Abeln, M. Eberhard, T. Kolb, H. Leibold, J. Sauer, D. Stapf, B. Zimmerlin, The bioliq process for producing synthetic transportation fuels, Wiley Interdisciplinary Reviews: Energy Environ. 6 (3) (2017) 236.

[21] D.C. Dayton, R.J. French, T.A. Milne, Direct observation of alkali vapor release during biomass combustion and gasification. 1. Application of molecular beam/ mass spectrometry to switchgrass combustion, Energy Fuel. 9 (5) (1995) 855-865.

[22] T.A. Milne, M.N. Soltys, Direct mass-spectrometric studies of the pyrolysis of carbonaceous fuels: I. A flame-pyrolysis molecular-beam sampling technique, J. Anal. Appl. Pyrol. 5 (2) (1983) 93-110.

[23] J. Tanner, S. Bhattacharya, M. Blasing, M. Müller, High-temperature pyrolysis and $\mathrm{CO} 2$ gasification of Victorian brown coal and Rhenish lignite in an entrained flow reactor, AIChE J. 62 (6) (2016) 2101-2111.

[24] S. Seebold, M. Eberhard, G. Wu, E. Yazhenskikh, D. Sergeev, T. Kolb, M. Müller, Thermophysical and chemical properties of bioliq slags, Fuel 197 (2017) 596-604.

[25] S.V. Vassilev, D. Baxter, L.K. Andersen, C.G. Vassileva, An overview of the chemical composition of biomass, Fuel 89 (2010) 913-933.

[26] J.M. Johansen, J.G. Jakobsen, F.J. Frandsen, P. Glarborg, Release of K, Cl, and S during pyrolysis and combustion of high-chlorine biomass, Energy Fuel. 25 (11) (2011) 4961-4971.

[27] F.J. Frandsen, S.C. van Lith, R. Korbee, P. Yrjas, R. Backman, I. Obernberger, T. Brunner, M. Joller, Quantification of the release of inorganic elements from biofuels, Fuel Process. Technol. 88 (11) (2007) 1118-1128.

[28] D.C. Dayton, B.M. Jenkins, S.Q. Turn, R.R. Bakker, R.B. Williams, D. Belle-Oudry, L.M. Hill, Release of inorganic constituents from leached biomass during thermal conversion, Energy Fuel. 13 (4) (1999) 860-870.

[29] H. Wu, M. Castro, P.A. Jensen, F.J. Frandsen, P. Glarborg, K. Dam-Johansen, M. Røkke, K. Lundtorp, Release and transformation of inorganic elements in combustion of a high-phosphorus fuel, Energy Fuel. 25 (7) (2011) 2874-2886

[30] D.M. Keown, G. Favas, J.-i. Hayashi, C.-Z. Li, Volatilisation of alkali and alkaline earth metallic species during the pyrolysis of biomass: differences between sugar cane bagasse and cane trash, Bioresour. Technol. 96 (14) (2005) 1570-1577.

[31] P.A. Jensen, F.J. Frandsen, K. Dam-Johansen, B. Sander, Experimental investigation of the transformation and release to gas phase of potassium and chlorine during straw pyrolysis, Energy Fuel. 14 (6) (2000) 1280-1285.

[32] J.N. Knudsen, P.A. Jensen, K. Dam-Johansen, Transformation and release to the gas phase of $\mathrm{Cl}, \mathrm{K}$, and $\mathrm{S}$ during combustion of annual biomass, Energy Fuel. 18 (5) (2004) 1385-1399. 
[33] P.A. Tchoffor, K.O. Davidsson, H. Thunman, Transformation and release of potassium, chlorine, and sulfur from wheat straw under conditions relevant to dual fluidized bed gasification, Energy Fuel. 27 (12) (2013) 7510-7520.

[34] H. Zhao, Q. Song, Q. Yao, Release and transformation of $\mathrm{K}$ and $\mathrm{Cl}$ during the pyrolysis of KCl-loaded cellulose, Fuel 226 (2018) 583-590.

[35] S.C. van Lith, P.A. Jensen, F.J. Frandsen, P. Glarborg, Release to the gas phase of inorganic elements during wood combustion. Part 2: influence of fuel composition, Energy Fuel. 22 (3) (2008) 1598-1609.

[36] K.O. Davidsson, B.J. Stojkova, J.B.C. Pettersson, Alkali emission from birchwood particles during rapid pyrolysis, Energy Fuel. 16 (5) (2002) 1033-1039.

[37] Z.-H. Zhang, Q. Song, Q. Yao, R.-M. Yang, Influence of the atmosphere on the transformation of alkali and alkaline earth metallic species during rice straw thermal conversion, Energy Fuel. 26 (3) (2012) 1892-1899.

[38] J.N. Knudsen, P.A. Jensen, W. Lin, F.J. Frandsen, K. Dam-Johansen, Sulfur transformations during thermal conversion of herbaceous biomass, Energy Fuel. 18 (3) (2004) 810-819.

[39] M. Blasing, M. Müller, Release of alkali metal, sulphur, and chlorine species from high temperature gasification of high- and low-rank coals, Fuel Process. Technol. 106 (2013) 289-294.

[40] D. Porbatzki, M. Stemmler, M. Müller, Release of inorganic trace elements during gasification of wood, straw, and miscanthus, Biomass Bioenergy 35 (2011) S79-S86.

[41] C. Dupont, S. Jacob, K.O. Marrakchy, C. Hognon, M. Grateau, F. Labalette, D. Da Silva Perez, How inorganic elements of biomass influence char steam gasification kinetics, Energy 109 (Supplement C) (2016) 430-435.
42] A. van der Drift, H. Boerrigter, B. Coda, M.K. Cieplik, K. Hemmes, Entrained flow gasification OF biomass, ECN Chemscope 4 (39) (2004) 1-58.

[43] C. Ma, R. Backman, M. Ohman, Thermochemical equilibrium study of slag formation during pressurized entrained-flow gasification of woody biomass, Energy Fuel. 29 (7) (2015) 4399-4406.

[44] C. Ma, M. Carlborg, H. Hedman, J. Wennebro, F. Weiland, H. Wiinikka, R. Backman, M. Ohman, Ash formation in pilot-scale pressurized entrained-flow gasification of bark and a bark/peat mixture, Energy Fuel. 30 (12) (2016) 10543-10554

[45] T. Okuno, N. Sonoyama, J.-i. Hayashi, C.-Z. Li, C. Sathe, T. Chiba, Primary release of alkali and alkaline earth metallic species during the pyrolysis of pulverized biomass, Energy Fuel. 19 (5) (2005) 2164-2171.

[46] D.M. Quyn, H. Wu, S.P. Bhattacharya, C.-Z. Li, Volatilisation and catalytic effects of alkali and alkaline earth metallic species during the pyrolysis and gasification of Victorian brown coal. Part II. Effects of chemical form and valence, Fuel 81 (2) (2002) 151-158.

[47] P. Thy, B.M. Jenkins, S. Grundvig, R. Shiraki, C.E. Lesher, High temperature elemental losses and mineralogical changes in common biomass ashes, Fuel 85 (5) (2006) 783-795.

48] A. Mueller, P. Stoesser, T. Kolb, Biomass Char Gasification: Study on Reaction Kinetics Using a High-Pressure Thermogravimetric Analyzer, 39th International Technical Conference on Clean Coal and Fuel Systems, 2014, pp. 744-755. 
Karlsruher Institut für Technologie

\section{Repository KITopen}

Dies ist ein Postprint/begutachtetes Manuskript.

Empfohlene Zitierung:

Mielke, K.; Kolb, T.; Müller, M.

Chemical fractionation of inorganic constituents in entrained flow gasification of slurry from straw pyrolysis.

2020. Biomass and bioenergy, 141.

doi: $10.5445 / I R / 1000123308$

Zitierung der Originalveröffentlichung:

Mielke, K.; Kolb, T.; Müller, M.

Chemical fractionation of inorganic constituents in entrained flow gasification of slurry from straw pyrolysis.

2020. Biomass and bioenergy, 141, Art.-Nr. 105732.

doi:10.1016/j.biombioe.2020.105732

Lizenzinformationen: $\underline{\text { CC BY-NC-ND } 4.0}$ 